\title{
Role of 5-hydroxytryptamine type 3 receptors in rat intestinal fluid and electrolyte secretion induced by cholera and Escherichia coli enterotoxins
}

F H Mourad, L J D O'Donnell, J A Dias, E Ogutu, E A Andre, J L Turvill, M J G Farthing

\begin{abstract}
Cholera toxin and Escherichia coli heat labile toxin (LT) induced intestinal secretion has in the past been attributed exclusively to an increase in intracellular cAMP whereas $E$ coli heat stable toxin (ST) induced secretion is mediated through cGMP. Evidence is accumulating on the importance of 5-hydroxytryptamine (5-HT) in cholera toxin induced secretion, but its role in LT and ST is not well established. This study therefore investigated in vivo the effect of $5-\mathrm{HT}_{3}$ receptor antagonist, granisetron, on intestinal fluid and electrolyte secretion induced by cholera toxin, LT, and ST. Granisetron $(30,75,150$, or $300 \mu \mathrm{g} / \mathrm{kg})$ was given subcutaneously to adult male Wistar rats 90 minutes before instillation of $75 \mu \mathrm{g}$ cholera toxin or $50 \mu \mathrm{g}$ LT in isolated whole small intestine. In situ small intestinal perfusion was performed with an iso-osmotic plasma electrolyte solution (PES) to assess fluid movement. In a second group of animals, granisetron (300 $\mu \mathrm{g} / \mathrm{kg}$ ) was given subcutaneously and two hours later small intestinal perfusion with PES containing $200 \mu \mathrm{g} / \mathrm{l}$ ST was performed. Cholera toxin induced net fluid secretion (median $-50.1 \mu \mathrm{l} / \mathrm{min} / \mathrm{g}$ (interquartile range -59.5 to $-29 \cdot 8$ )) was found to be dose dependently decreased or abolished by granisetron (plateau effect at $75 \mu \mathrm{g} / \mathrm{kg}$ : $18(-7 \cdot 8$ to 28$), \quad \mathrm{p}<0.01)$. Granisetron in high dose $(300 \mu \mathrm{g} / \mathrm{kg})$, however, failed to prevent LT or ST induced secretion $(-52(-121$ to -71$) v$ $-31(-44$ to -18$)$, and $(-39(-49$ to 17$) v$ $(-22(-39$ to -3$))$, respectively). Sodium and chloride movement paralleled that of fluid. In conclusion, these data show that 5-HT and 5-HT 3 receptors play an important part in cholera toxin induced secretion but are not involved in $E$ coli heat stable or heat labile toxin induced secretion

(Gut 1995; 37: 340-345)
\end{abstract}

Keywords: 5-hydroxytryptamine, cholera toxin, $E$ coli.

Correspondence to: Professor M J G Farthing, Digestive Diseases Research Centre, Medical College of Charterhouse Square,
London EC1M 6BQ.

Accepted for publication 18 January 1995 Intestinal secretion induced by cholera toxin and the structurally related enterotoxin, Escherichia coli heat labile toxin (LT) has been in the past, attributed solely to the activation of adenylate cyclase with the corresponding increase in intracellular cAMP. Evidence has been accumulating, however, on the importance of 5-hydroxytryptamine (5-HT) present in enterochromaffin cells and of the enteric nervous system in the pathophysiology of cholera toxin induced secretion. ${ }^{1-3}$ Nilsson et al have shown that enterochromaffin cells in the cat small intestine discharge their contents of 5-HT after exposure to cholera toxin. ${ }^{1}$ Plasma and gut lumen $5-\mathrm{HT}$ is increased in human volunteers exposed to a subclinical dose of cholera toxin. ${ }^{45}$ In addition, inhibition of cholera toxin induced secretion by neuronal blockade using tetrodotoxin and lidocaine has unveiled the importance of the enteric nervous system in the secretory process. ${ }^{6}$ On the basis of these findings, it has been proposed that cholera toxin promotes cAMP mediated release of 5-HT from enterochromaffin cells, which then stimulates dendrites immediately adjacent to the intestinal epithelium. ${ }^{78}$ Beubler et al have found that pre-treatment with $5-\mathrm{HT}_{3}$ antagonists partially prevents cholera toxin induced fluid secretion in rat jejunum. ${ }^{3} \mathrm{LT}$ is structurally, immunologically, and functionally related to cholera toxin. ${ }^{9} 10$ LT, like cholera toxin, possesses five $\beta$ subunits and a single $\alpha$ subunit and binds to the same receptor on enterocytes (GM1 ganglioside) leading to activation of adenylate cyclase and increase in intracellular cAMP. ${ }^{911}$ Whether 5-HT participates in the secretory process induced by LT has not been previously studied.

The $E$ coli heat stable toxin (ST) binds to a specific receptor on the apical membrane of the enterocyte and exhibits a very rapid onset of action by inhibiting electroneutral $\mathrm{Na}^{+} \mathrm{Cl}^{-}$ absorption and inducing $\mathrm{Cl}^{-}$secretion, a process that occurs in parallel with increased values of intracellular cGMP. ${ }^{12-14}$ Although the enteric nervous system has been shown to play an important part in ST induced secretion, ${ }^{15}$ the neurotransmitters involved are not yet fully characterised. ${ }^{14}{ }^{16-19}$ As $5-\mathrm{HT}$ is a neurotransmitter and as $5-\mathrm{HT}_{3}$ receptors are present exclusively on neurons, ${ }^{2021}$ it would be interesting therefore to discover if 5-HT plays a part in the secretory process induced by ST.

The aim of our study was to investigate the effect of 5-HT type 3 receptor antagonist granisetron on cholera toxin induced secretion and the role of 5-HT and 5- $\mathrm{HT}_{3}$ receptors in 
the pathophysiology of cholera toxin, LT, and ST induced intestinal secretion using an animal model in vivo.
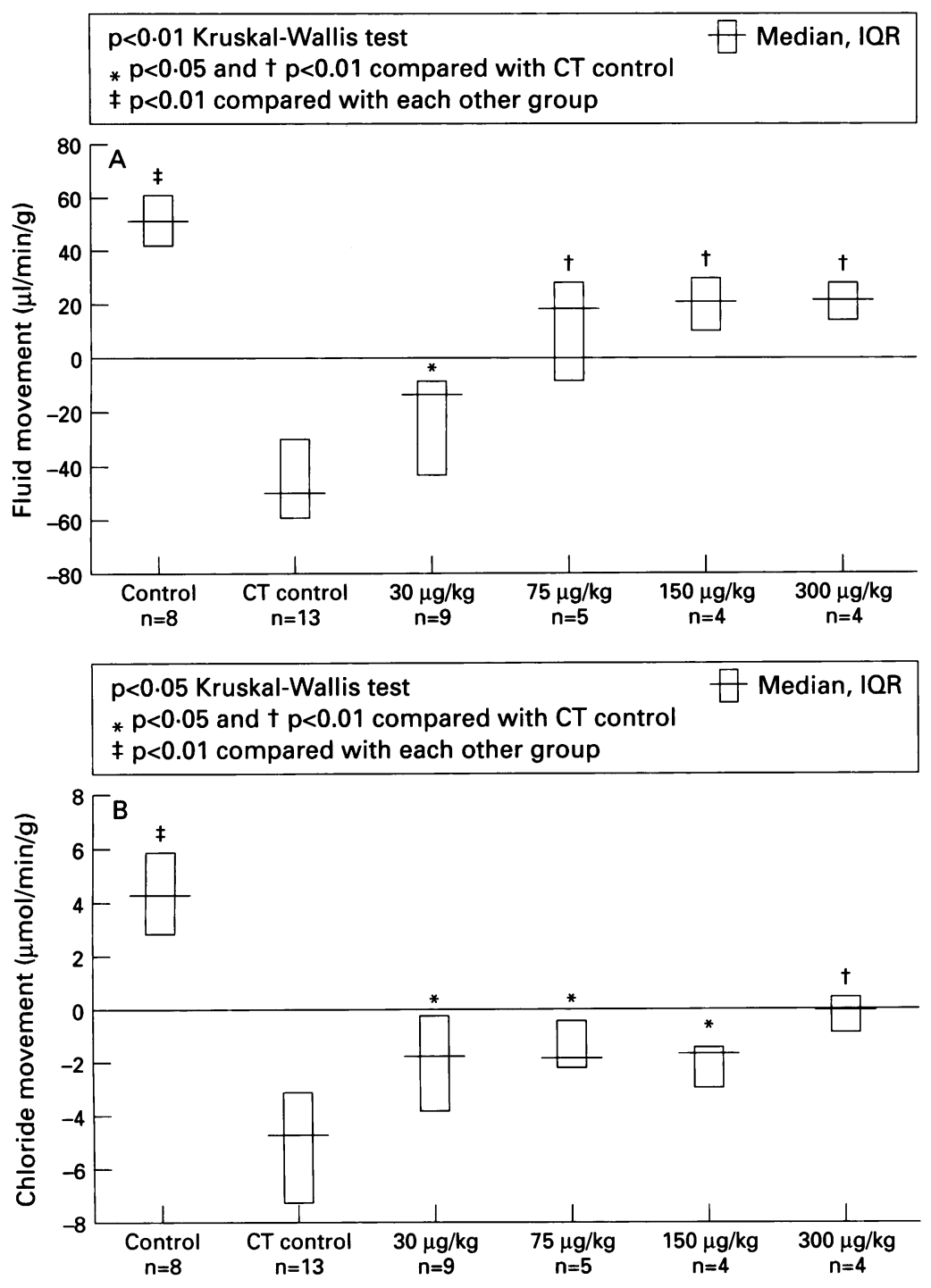

$\mathrm{p}<0.01$ Kruskal-Wallis test * NS and $+p<0.05$ compared with CT control $\ddagger p<0.01$ compared with each other group

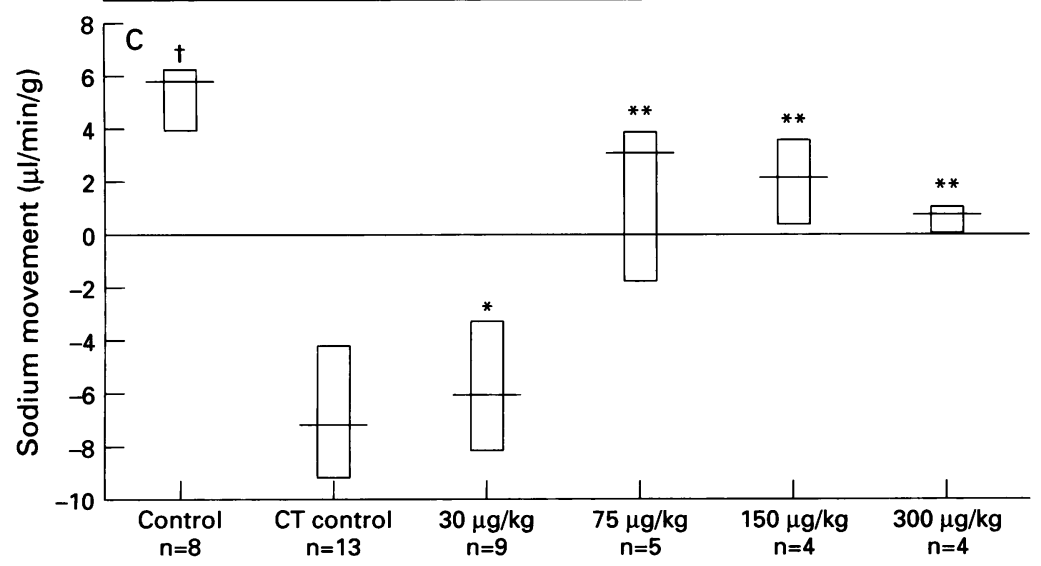

Figure 1: Effect of cholera toxin $75 \mu \mathrm{g}$ on (A) fluid, (B) chloride, and (C) sodium movement in control and in rats pre-treated with subcutaneous granisetron 30,75, 150, and $300 \mu \mathrm{g} / \mathrm{kg}$. Fluid movement is expressed in $\mu \mathrm{l} / \mathrm{min} / \mathrm{g}$, chloride and sodium in umol/min/g dry intestinal weight. Results are expressed as median and interquartile range $(I Q R)$; positive values denote absorption and negative values denote secretion. KruskalWallis test is used to study the effect of different doses of granisetron on fuid and electrolyte movement, and Wilcoxon rank sum test is used to test the differences between pairs.

\section{Methods}

Cholera toxin and $L T$ experiments

Male adult Wistar rats (180-220 g body weight) were fasted for 18 hours with free access to water. The rats were anaesthetised with intraperitoneal injection of sodium pentobarbitone $(60 \mathrm{mg} / \mathrm{kg})$ and maintained throughout the experiments by interval intraperitoneal injections $(15-30 \mathrm{mg} / \mathrm{kg}$ ) as necessary. The abdomen was opened through a midline incision and cannulas were inserted into the small intestine proximally $(5 \mathrm{~cm}$ distal to the duodenojejunal junction) and distally in the terminal ileum (1-2 cm proximal to ileocaecal junction), and fixed by ligation as described previously. ${ }^{22}$ The isolated intestinal segment was gently flushed with isotonic saline $\left(37^{\circ} \mathrm{C}\right)$ and then air was injected to clear the small intestine of residual content before the instillation of $75 \mu \mathrm{g}$ cholera toxin in $6 \mathrm{ml}$ of isotonic saline or $6 \mathrm{ml}$ isotonic saline alone (controls) and clamping both proximal and distal cannulas. The intestine was returned to the abdominal cavity and the abdomen was closed. After two hours, the clamps were removed and the intestine was perfused at a rate of $0.5 \mathrm{ml} / \mathrm{min}$ with plasma electrolyte solution (PES) containing $\mathrm{Na} 140, \mathrm{~K} 4, \mathrm{Cl}$ $104, \mathrm{HCO}_{3} 40 \mathrm{mmol} / \mathrm{l}$ to which $5 \mathrm{~g}$ polyethylene glycol 4000 (PEG) and $4 \mu \mathrm{Ci} / 1$ of $\left[{ }^{14} \mathrm{C}\right]-\mathrm{PEG}$ were added. Thirty minutes were allowed to elapse to ensure establishment of a steady state after which three consecutive 10 minute collections of the effluent were obtained from distal cannula. This dose of cholera toxin was used as it has previously been shown to cause maximum fluid secretion in this model. ${ }^{23}$ Similarly, LT was given in a dose of $50 \mu \mathrm{g}$ or $75 \mu \mathrm{g}$ to get the same level of fluid secretion as cholera toxin. The 5- $\mathrm{HT}_{3}$ antagonist, granisetron, was given subcutaneously as a dose of $30,75,150$, or 300 $\mu \mathrm{g} / \mathrm{kg}$ in $0.3 \mathrm{ml}$ saline (for the cholera toxin experiments) and $300 \mu \mathrm{g} / \mathrm{kg}$ (for the LT experiments) at the same time as the anaesthetic. Control animals were given subcutaneously saline without granisetron. Animals were kept at $37^{\circ} \mathrm{C}$ using a heat pad and an overhead lamp. At the end of the experiments the rats were killed by an overdose of pentobarbitone and the perfused intestinal segment was removed, rinsed, blotted, and desiccated in an oven at $100^{\circ} \mathrm{C}$ to obtain the dry weight. The samples of effluent were analysed immediately or kept frozen at $-20^{\circ} \mathrm{C}$ and analysed within two weeks.

\section{ST experiments}

In experiments with ST, a $25 \mathrm{~cm}$ segment of jejunum starting $5 \mathrm{~cm}$ distal to the duodenojejunal junction was perfused with PES containing $\left[{ }^{14} \mathrm{C}\right]-\mathrm{PEG}$ to which $200 \mu \mathrm{g} / \mathrm{l} \mathrm{ST}$ (equivalent to 50000 mouse units) ${ }^{24}$ was added. After 30 minutes' perfusion to establish steady state, three consecutive 10 minute collections of the effluent were obtained. Granisetron $300 \mu \mathrm{g} / \mathrm{kg}$ or saline was given subcutaneously with the anaesthetic. Steady state 


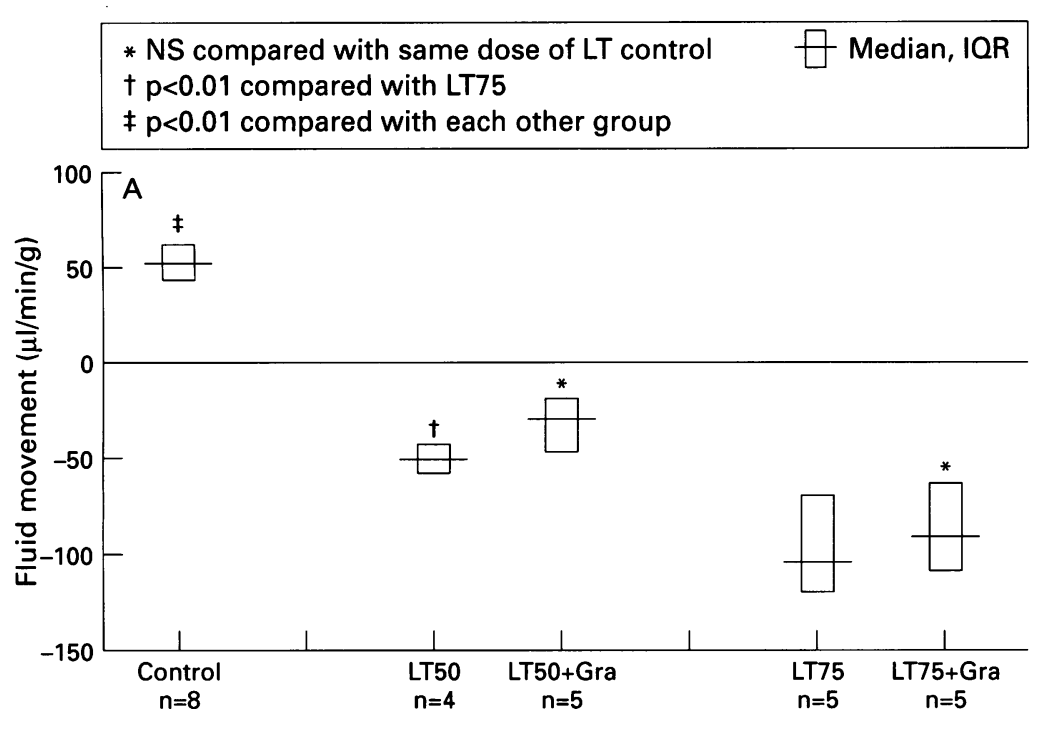

\begin{tabular}{|l}
$*$ NS compared with same dose of LT control \\
$+p<0.05$ compared with LT75 \\
$\neq p<0.01$ compared with each other group
\end{tabular}
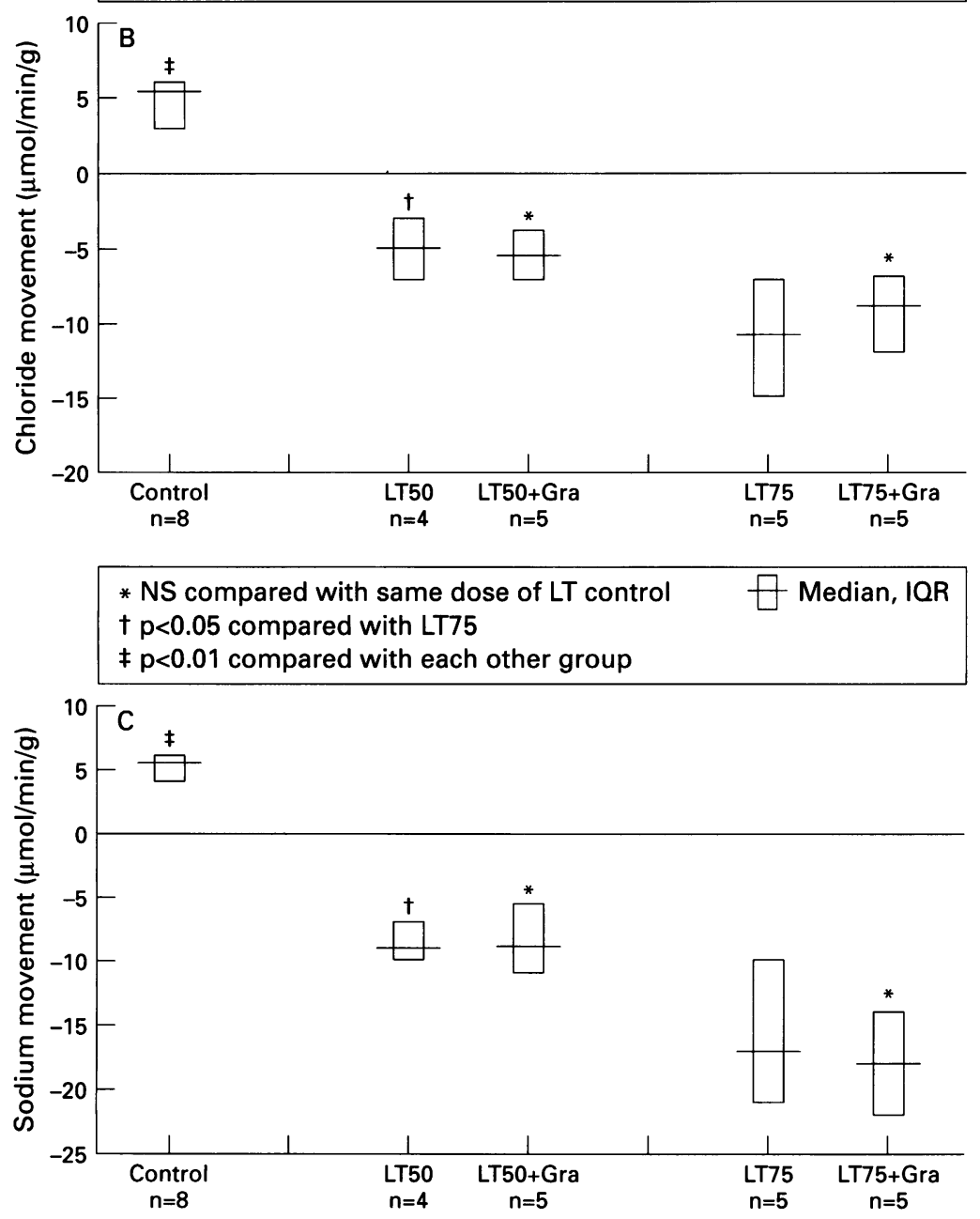

Figure 2: Effect of $\mathrm{E}$ coli heat labile toxin $50 \mu \mathrm{g}$ (LT50) and $75 \mu \mathrm{g}$ (LT75) on (A) fluid, $(B)$ chloride, and $(C)$ sodium movement in control and in rats pre-treated with subcutaneous granisetron (Gra) $300 \mu \mathrm{g} / \mathrm{kg}$. Fluid movement is expressed in $\mu \mathrm{l} / \mathrm{min} / \mathrm{g}$, chloride and sodium in $\mu \mathrm{mol} / \mathrm{min} / \mathrm{g}$ dry intestinal weight. Results are expressed as median and interquartile range (IQR); positive values denote absorption and negative values denote secretion. Wilcoxon rank sum test is used to test the differences between pairs.

condition was shown by less than $5 \%$ variation in water movement between consecutive 10 minute collections and also the values were accepted only if recovery of radioactive PEG fell between 95 and $105 \% .^{22} 23$

\section{Analytical methods}

$\left[{ }^{14} \mathrm{C}\right]-\mathrm{PEG}$ concentrations in the effluent were measured in triplicate by liquid scintillation spectroscopy in LKB Wallac Ultra-beta 1210 scintillation counter. Sodium and potassium concentrations were determined by a flame photometer (Instrument Laboratories 943), and chloride concentrations by Chemlab (CMMI chloridemeter).

The mean of the net fluid and solute movement of the three consecutive effluent samples was calculated and expressed respectively as $\mu \mathrm{l} / \mathrm{min} / \mathrm{g}$ and $\mu \mathrm{mol} / \mathrm{min} / \mathrm{g}$ of dry intestinal weight. Positive values denote net absorption and negative values net secretion.

\section{Materials}

Cholera toxin, ST, and LT were obtained from Sigma Chemical Company. The 5- $\mathrm{HT}_{3}$ receptor antagonist, granisetron was supplied by SmithKline Beecham, UK. Granisetron is considered a specific $5-\mathrm{HT}_{3}$ receptor antagonist in the gut. ${ }^{25}$ Radiolabelled polyethylene glycol $\left(\left[{ }^{14} \mathrm{C}\right]-P E G\right.$ 4000) was obtained from Amersham International and all other chemicals were supplied by British Drug House (BDH Chemicals).

\section{Statistics}

Results are expressed as median and interquartile range in each group of animals studied. Differences in fluid and solute movement with different doses of granisetron were examined using the Kruskal-Wallis test for non-parametric multiple comparisons, and differences between pairs in all other experiments were tested using the Wilcoxon rank sum test.

\section{Results}

Cholera toxin and $L T$ experiments

Net fluid secretion occurred in all the animals receiving cholera toxin (median $-50.1 \mu \mathrm{l} / \mathrm{min} / \mathrm{g}$ (interquartile range -59.5 to -29.8$) ; n=13$ ) (Fig 1A). Chloride movement paralleled that of fluid $(-4.7 \mu \mathrm{mol} / \mathrm{min} / \mathrm{g}(-7 \cdot 1$ to $-2 \cdot 2)$ ) (Fig 1B). Granisetron dose dependently reduced fluid and electrolyte secretion $(p<0.01$, Kruskal-Wallis test). Granisetron at $30 \mu \mathrm{g} / \mathrm{kg}$ significantly decreased cholera toxin induced fluid secretion $(-13.5(-43.1$ to -8.7$), n=9$; $\mathrm{p}<0.03)$ and at $75 \mu \mathrm{g} / \mathrm{kg}$ reversed fluid secretion to absorption ( 18 ( 7.8 to 28$), n=5 ; p<0.01$ ) but fluid absorption was still less than that in normal non-secreting controls ( 51 (42 to 61 ), $\mathrm{n}=8$; $\mathrm{p}<0.01$ ) (Fig 1A). Higher doses of granisetron (150 and $300 \mu \mathrm{g} / \mathrm{kg}$ ) did not increase fluid absorption further (21 (10 to 30 ), $n=4$ and 21 (15 to 28$), n=4$, respectively). Chloride secretion was also significantly reduced in a dose dependent manner by granisetron (Fig 1B). Sodium secretion was unaffected by the low dose of granisetron, however, it was reversed to absorption by a dose of $75 \mu \mathrm{g} / \mathrm{kg}$ or higher (Fig 1C). Granisetron had no effect on fluid movement in normal non-secreting intestine (49 (29 to 56$), n=9$; NS). 

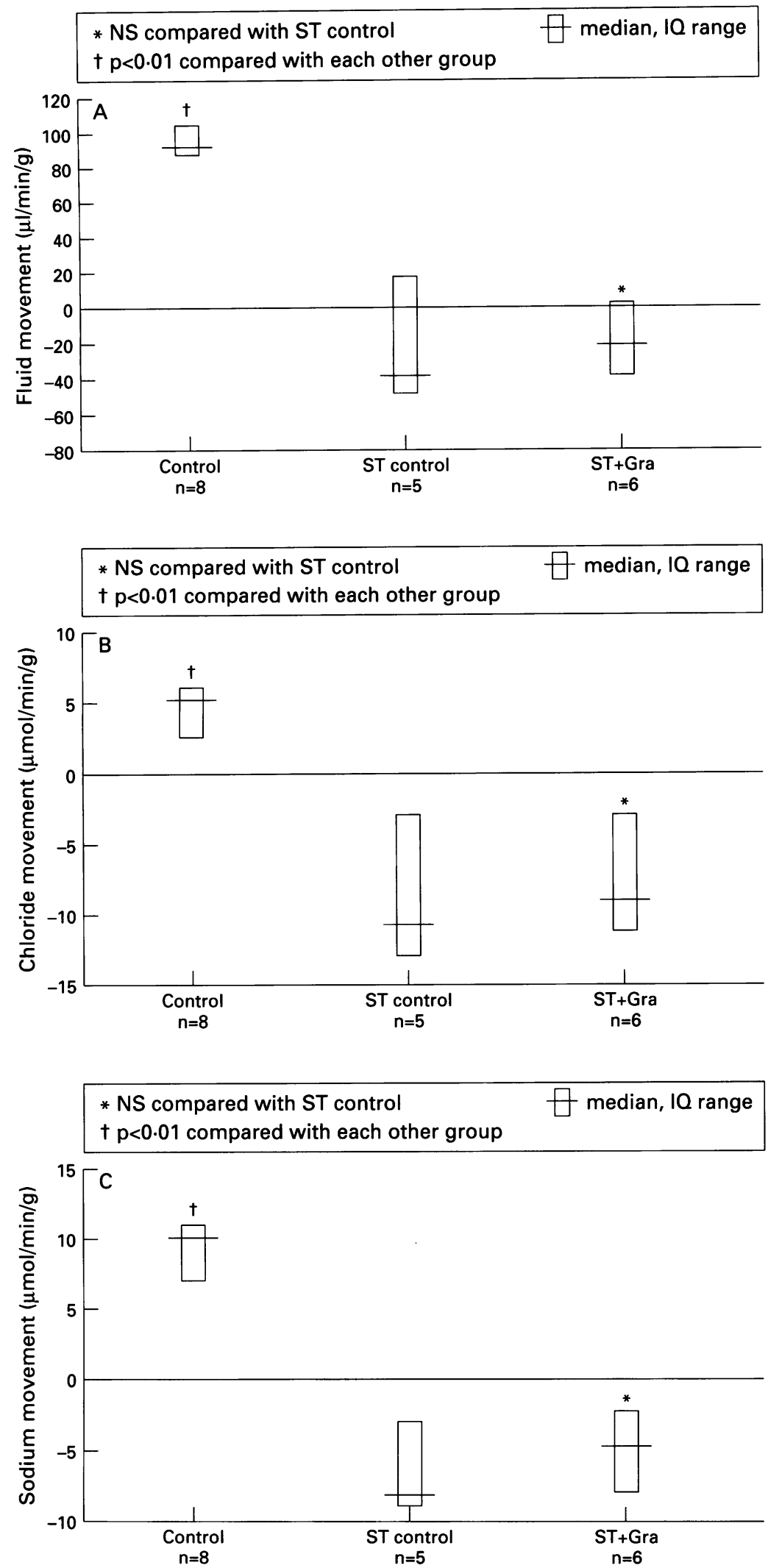

Figure 3: Effect of $\mathrm{E}$ coli heat stable toxin on $(A)$ fluid, $(B)$ chloride, and $(C)$ sodium movement in control and in rats pre-treated with subcutaneous granisetron (Gra) 300 $\mu \mathrm{g} / \mathrm{kg}$. Fluid movement is expressed in $\mu \mathrm{l} / \mathrm{min} / \mathrm{g}$, chloride and sodium in $\mu \mathrm{mol} / \mathrm{min} / \mathrm{g} d r y$ intestinal weight. Results are expressed as median and interquartile range (IQR); positive values denote absorption and negative values denote secretion. Wilcoxon rank sum test is used to test the differences between pairs.

LT at a dose of $75 \mu \mathrm{g}$ caused marked fluid secretion $(-106(-121$ to -71$))$ and at $50 \mu \mathrm{g}$ the secretion was similar to that seen with $75 \mu \mathrm{g}$ cholera toxin $(-52(-59$ to -44$))$. At both doses of LT, and in contrast with cholera toxin, granisetron $(300 \mu \mathrm{g} / \mathrm{kg})$ had no effect on fluid and electrolyte secretion (Fig 2).

\section{ST experiments}

Perfusing the small intestine with a solution containing ST caused appreciable fluid, chloride, and sodium secretion $(-39$ ( -49 to 17) $\mu \mathrm{l} / \mathrm{min} / \mathrm{g},-10.7(-13$ to -3$) \mu \mathrm{mol} / \mathrm{min} / \mathrm{g}$, and $-6(-9$ to -3$)$, respectively; $n=5)$ (Fig 3$)$. Granisetron in a dose of $300 \mu \mathrm{g} / \mathrm{kg}$ had no effect on fluid and electrolyte secretion (Fig 3).

\section{Discussion}

We have shown that the $5-\mathrm{HT}_{3}$ receptor antagonist granisetron can dose dependently prevent cholera toxin induced fluid and electrolyte secretion. Our experiments further support the importance of 5-HT in cholera toxin induced fluid secretion. It is known that cholera toxin simulates adenylate cyclase and increases intracellular cAMP not only in enterocytes but also in many other cell types. In enterochromaffin cells, this increase in cAMP leads to their degranulation and subsequent 5-HT release, ${ }^{25}$ which closely correlates with changes in fluid movement. ${ }^{3} 5-\mathrm{HT}$ induced secretion, in contrast with cholera toxin, does not use cAMP as a mediator ${ }^{26}$ but seems to increase calcium gating in epithelial cells ${ }^{26} 27$ or activate intestinal neuronal reflexes, or both. ${ }^{28}$ Cholera toxin has also been shown to activate nerve reflexes as part of its secretory action, ${ }^{6}$ which can be reversed by neuronal blockade. In our experiments, as well as in a previous study, ${ }^{3}$ cholera toxin induced secretion was reversed by 5-HT type 3 receptor antagonism. As $5-\mathrm{HT}_{3}$ receptors are present exclusively on neurons, ${ }^{20} 21$ our findings provide further evidence for an important role of 5-HT in cholera toxin induced fluid secretion as a result of a stimulatory effect on neuronal structures.

The pathophysiology of diarrhoea caused by other enterotoxins has not been as extensively investigated as that caused by cholera toxin. LT, which is structurally similar to cholera toxin, binds to the same receptor on enterocytes (GM1 ganglioside) and has been shown to stimulate adenylate cyclase with the corresponding increase in cAMP production. ${ }^{911}$ The two toxins are not completely identical in their amino acid composition, ${ }^{9-11} 30$ however, and their binding affinity is different. ${ }^{10}{ }^{30}$ Griffith et $a l^{30}$ have shown that intestinal brush borders from Wistar rats bind 20-30 times more LT than cholera toxin and that LT binds to a variety of brush border galactoproteins only weakly recognised by cholera toxin. In our experiments, the differential effect of $5-\mathrm{HT}_{3}$ receptor antagonism on cholera toxin and LT suggest that there are other fundamental differences in the pathophysiology of diarrhoea caused by these enterotoxins. Although a dose of LT that causes the same amount of secretion as cholera toxin was used, $5-\mathrm{HT}_{3}$ antagonism had no effect on fluid and electrolyte secretion. Whereas 5 -HT plays an important part in cholera toxin induced secretion, it seems it had no role in LT induced secretion. 
It is likely that binding of LT to additional receptors on enterocytes plays a pathophysiologic part in the secretory process. Holmgren et $a l^{31}$ have shown in vivo that blocking cholera toxin receptors by the inactive $B$ subunits $\left(\mathrm{CT}_{\mathrm{B}}\right)$ does not prevent LT induced secretion; however, blocking LT receptors by $\mathrm{LT}_{\mathrm{B}}$ totally prevent cholera toxin induced secretion showing that LT binds to receptors not recognised by cholera toxin and induces the same amount of secretion. Although LT causes an increase in cAMP, it is not known if this leads to enterochromaffin cells degranulation and consequently 5-HT release; measurement of enterochromaffin cell degranulation or luminal 5-HT would clarify this point.

The role of cGMP in ST induced intestinal secretion is well established.131432 Whether cGMP alone or other mediators are also involved is not known. It has been shown that, like in cholera toxin, the enteric nervous system is also involved in ST induced secretion as shown by the inhibitory effect of hexamethonium, lidocaine, and tetrodotoxin. ${ }^{15} 1718$ The involvement of prostaglandins is not well established and there is controversy about the effect of indomethacin on ST induced secretion. 3334 Beubler et al ${ }^{35-37}$ have recently suggested that ST induces fluid secretion predominantly by local 5-HT release. $5-\mathrm{HT}_{3}$ antagonism failed to prevent ST induced secretion in vivo in our experiments, however, although it was effective in reversing cholera toxin induced secretion. Our results are against a role for 5-HT in the pathophysiology of ST induced intestinal secretion and are in accordance with two previous findings. Forsberg et $a l^{38}$ have shown in vitro that CGMP, in contrast with cAMP, does not lead to an increase in serotonin release from enterochromaffin cells. Secondly, Rolfe et al ${ }^{17} 18$ using intestinal segments mounted in Ussing chambers failed to find any difference in the change in short circuit current between 5HT desensitised rat terminal ileal tissues and controls, after exposure to ST; in addition cGMP induced a change in short circuit current in 5-HT desensitised muscle stripped sheets. It was concluded that both ST $E$ coli and CGMP can both activate intestinal electrogenic secretion in vitro without the mediation of 5-HT.

In conclusion, our findings support the view that 5-HT participates in cholera toxin induced secretion, presumably as a result of adenylate cyclase activation and 5-HT release from enterochromaffin cells, but not in LT or ST secretion.

1 Nilsson O, Cassutto J, Larsson PA, Jodal M, Lidberg E, Ahlman $\mathrm{H}$, et al. 5-Hydroxytryptamine and cholera secretion: a histochemical and physiological study in cats. Gut 1983; 24: 542-8

2 Beubler E, Kollar G, Saria A, Bukhave K, Rask-Madsen J. Involvement of 5-hydroxytryptamine, prostaglandin $\mathrm{E}_{2}$ and cyclic adenosine monophosphate in cholera toxininduced fluid secretion in the small intestine of the rat in vivo. Gastroenterology 1989; 96: 368-76.

3 Beubler E, Horina G. $5-\mathrm{HT}_{2}$ and $5-\mathrm{HT}_{3}$ receptor subtypes mediate cholera toxin-induced intestinal fluid secretion in mediate cholera toxin-induced intestinal
the rat. Gastroenterology 1990; 99: 83-9.

4 Thillainayagam AV, Dias JA, Shirgi-Degen A, Beubler E, Clark ML, Farthing MJG. Supportive evidence that 5Clark ML, Farthing MJG. Supportive evidence that 5-
hydroxytryptamine (5-HT) is a mediator of cholera toxin (CT) induced secretion in man. Gastroenterology 1991. 100: A199.
5 Bearcroft CP, Taylor TM, Perret D, Farthing MJG. 5Hydroxytryptamine release into human jejunum by Hydroxytryptamine release into human jejun
cholera toxin. Gastroenterology 1992;102: A199.

6 Cassuto J, Jodal M, Tuttle R, Lundgren O. On the role of intramural nerves in the pathogenesis of choleraic secre ion. Scand $\mathcal{F}$ Gastroenterol 1981; 16: 377-84

7 Lundgren O, Svanik J, Jivegard L. Enteric nervous system. I. Physiology and pathophysiology of the intestinal tract. Dig Dis Sci 1989; 34: 264-83.

8 Jodal M. Neuronal influence on intestinal transport. 7 Intern Med 1990; 228: 125-32.

9 Sack BS. Enterotoxigenic Escherichia coli: identification and characterisation. 7 Infect Dis 1980; 142: 279-85.

10 Spangler BD. Structure and function of cholera toxin and the related Escherichia coli heat-labile enterotoxin. the related Escherichia coli

11 Field $M$. Modes of action of enterotoxin from Vibrio cholerae and Escherichia coli. Rev Infect Dis 1979; 1 $918-25$.

12 Guarino A, Cohen M, Thompson M, Dharmsathaphorn K, Giannella R. T84 cell receptor binding and guanylat cyclase activation by Escherichia coli heat stable toxin. $A m$ f Physiol 1987; 253: G775-80.

13 Scoot A, Forsyth GW, Kapitany RA, Roe WE, Hamilton DL. Effect of isolated heat stable enterotoxin produced by Escherichia coli on fluid secretion and cyclic nucleotide level in the jejunum of weanling pig. Can 7 Physiol Pharmacol 1980; 58: 772-7.

14 Hughes JM, Murad F, Chang B, Guerrant RL. Role of cyclic GMP in the action of heat stable enterotoxin of Escherichia coli. Nature 1978; 271: 755-6.

15 Eklund S, Jodal M, Lundgren $O$. The enteric nervous system participates in the secretory response to the heat stable enterotoxins of Escherichia coli in rats and cats Neuroscience 1985; 14: 673-81.

16 Eklund S, Karlstrom L, Rokacus A, Theodorsson E, Jodal $M$, Lundgren $O$. Effects of cholera toxin, Escherichia coli heat stable toxin and sodium deoxycholate on neurotensin release from the ileum in vivo. Regul Pept 1989; 26: 241-52.

17 Rolfe V, Levin RJ, Young A. Electrogenic secretion in rat intestine in vitro activated by E coli STa is not mediated by local release of 5-hydroxytryptamine. 7 Physiol 1992; 446: $107 \mathrm{P}$

18 Rolfe V, Levin RJ. Enterotoxin Escherichia coli STa activates a nitric oxide-dependent myenteric plexus secretory reflex in the rat ileum. F Physiol 1994; 475: 531-7.

19 Shirgi-Degen A, Beubler E. Significance of nitric oxide in the regulation of intestinal fluid transport in the rat jejunum in vivo. Gastroenterology 1994; 106: A2369.

20 Richardson BP, Engel G. The pharmacology and function of 5-HT 3 receptors. Trends Neurosci 1986; $9: 424-8$.

21 Hendriks R, Bornstein JC, Furness JB. Evidence for two types of 5-hydroxytryptamine receptors on secretomotor neurons of the guinea-pig ileum. Naunyn Schmiedebergs Arch Pharnacol 1989; 339: 409-14.

22 Rolston DDK, Borodo MM, Kelly MJ, Dawson AM Farthing MJG. Efficacy of oral rehydration solutions in a rat model of secretory diarrhoea. $\not$ Paediatr Gastroenterol rat model of secretory

23 Elliott EJ, Watson AJM, Walker-Smith JA, Farthing MJG Search for the ideal rehydration solution: studies in model of secretory diarrhoea. Gut 1991; 32: 1314-20.

24 Giannella RA. Suckling mouse model for detection of heat stable Escherichia coli enterotoxin: characteristics of the model. Infect Immun 1976; 14: 95-9.

25 Sanger GJ, Nelson DR. Selective and functional 5-hydroxytryptamine $_{3}$ receptor antagonism by BRL 43694 (granisetron). Eur f Pharmacol 1989; 159: 113-24

26 Beubler E, Bukhane K, Rask-Madsen J. Significance of calcium for the prostaglandin $E_{2}$ mediated secretory response to 5 -hydroxytryptamine in the small intestine of response to 5-hydroxytryptamine in the small inte
the rat in vivo. Gastroenterology 1986; 90: 1972-7.

27 Hardcastle J, Hardcastle PT, Noble JM. The involvement of calcium in the intestinal response to secretagogue in the calcium in the intestinal response
rat. $\mathcal{F}$ Physiol 1984; 355: 465-78.

28 Keast JR, Furness JB, Costa $M$. Investigations of nerve populations influencing ion transport that can be stimuated electrically by serotonin and by a nicotinic agonist. Naunyn Schmiedebergs Arch Pharmacol 1985; 331: 260-6.

29 Clements JD, Finkelstein RA. Isolation and characterisation of homogeneous heat-labile enterotoxins with high specific activity from Escherichia coli cultures. Infect Immun 1979; 24: 760-9.

30 Griffith SL, Critchley DR. Characterisation of the binding sites for Escherichia coli heat-labile toxin type I in intestinal brush borders. Biochim Biophys Acta 1991; 1075: 154-61

31 Holmgren J, Fredman P, Lindblad M, Svennerholm A-M Svennerholm L. Rabbit intestinal glycoprotein receptor for Escherichia coli heat-labile enterotoxin lacking affinity for cholera toxin. Infect Immun 1982; 38: 424-33.

32 Field M, Graf LH, Laid WJ, Smith PL. Heat stable enterotoxin Escherichia coli: In vitro effects on guanylate toxin Escherichia coli: In vitro effects on guanylate
cyclase activity, cyclic GMP concentration and ion transcyclase activity, cyclic GMP concentration and ion trans-
port in small intestine. Proc Natl Acad $S_{c i}$ USA 1978; 75: port in smat.

33 Greenberg RN, Murad F, Chang B, Robertson DC, Guerrant RL. Inhibition of Escherichia coli heat stable enterotoxin by indomethacin and chlorpromazine. Infect Immun 1980; 29: 908-13

34 Ahrens FA, Zhu B. Effect of indomethacin, acetazolamide, ethacrynate sodium and atropine on intestinal secretion mediated by Escherichia coli heat stable enterotoxin in pig jejunum. Can $\mathcal{F}$ Physiol Pharmacol 1982; 60: 1281-6. 
35 Beubler E, Badhri P, Degen A. Involvement of serotonin (5 HT) in fluid secretion induced by heat stable enterotoxin HT) in fluid secretion induced by heat stable
of $E$ coli (ST). $Z$ Gastroenterol 1990; 28: 415 .

36 Beubler E, Badhri P, Schirgi-Degen A. 5-HT receptor antagonists and heat-stable Escherichia coli enterotoxininduced effects in the rat. Eur $\mathcal{F}$ Pharmacol 1992; 219: 445-50.
37 Beubler E, Schirgi-Degen A, Gamse R. Inhibition of 5hydroxytryptamine and enterotoxin-induced fluid secrehydroxytryptamine and enterotoxin-induced fluid secre-
tion by 5 -HT receptor antagonists in the rat jejunum. Eur tion by 5-HT receptor antagonis

38 Forsberg EJ, Miller RJ. Regulation of serotonin release from rabbit intestinal enterochromaffin cells. $\mathcal{F}$ Pharmacol Exp Ther 1983; 227: 755-66. 